Canadian Journal of Higher Education

Revue canadienne d'enseignement supérieur

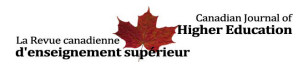

\title{
(Dis)Embodied Disclosure in Higher Education: A Co-Constructed Narrative
}

\section{Katie Aubrecht et Nancy La Monica}

Volume 47, numéro 3, 2017

URI : https://id.erudit.org/iderudit/1043235ar

DOI : https://doi.org/10.7202/1043235ar

Aller au sommaire du numéro

\section{Éditeur(s)}

Canadian Society for the Study of Higher Education

ISSN

2293-6602 (numérique)

Découvrir la revue

Citer cet article

Aubrecht, K. \& La Monica, N. (2017). (Dis)Embodied Disclosure in Higher Education: A Co-Constructed Narrative. Canadian Journal of Higher Education / Revue canadienne d'enseignement supérieur, 47(3), 1-15.

https://doi.org/10.7202/1043235ar

\section{Résumé de l'article}

Dans cet article, les auteures utilisent des méthodes auto-ethnographiques élaborées collaborativement pour explorer les dynamiques animant la signification de " divulgation » d'un handicap en milieux universitaire et collégial. Puisant dans leurs propres expériences comme étudiantes au cycle supérieur et chargées de cours à l'université et au collège, elles examinent les façons normales de concrétiser la divulgation et de lui donner toute son importance, comme s'il s'agissait d'une relation interpersonnelle et d'une forme tangible de labeur. Leur dialogue démontre la nature variée de la divulgation d'un handicap. Par exemple, un étudiant peut se déclarer handicapé afin d'accéder à un service académique, tandis qu’un chargé de cours ne se déclarera pas comme handicapé pour enseigner. Aubrecht se sert d'études phénoménologiques sur les handicaps pour analyser leur " divulgation » au croisement d'un handicap et d'une grossesse comme des moments corporels interposés (Draper, 2002). La Monica adopte la notion de " labeur émotionnel » de Hochschild's (1983) pour explorer comment le processus socio-spatial de la " divulgation " peut être une forme incorporable de « travail supplémentaire » (p. ex. : gérer la perception d’identité stigmatisée).
Copyright (c) Katie Aubrecht, Nancy La Monica, 2017

Attribution-NonCommercial-No Derivative Works 2.5 Canada
Ce document est protégé par la loi sur le droit d'auteur. L'utilisation des services d'Érudit (y compris la reproduction) est assujettie à sa politique d'utilisation que vous pouvez consulter en ligne.

https://apropos.erudit.org/fr/usagers/politique-dutilisation/ 
Canadian Journal of Higher Education Revue canadienne d'enseignement supérieur

Volume 47, No. 3, 2017, pages 1 - 15

\title{
(Dis)Embodied Disclosure in Higher Education: A Co-Constructed Narrative
}

\author{
Katie Aubrecht \\ Mount Saint Vincent University \\ Nancy La Monica \\ Seneca College
}

\begin{abstract}
In this paper we use co-constructed autoethnographic methods to explore the tensions that animate the meaning of "disclosure" in university and college environments. Drawing insight from our embodied experiences as graduate students and university/college course instructors, our collaborative counternarratives examine the ordinary ways that disclosure is made meaningful and material as a relationship and a form of embodied labour. Our dialogue illustrates the layered nature of disclosure-for example, self-disclosing as a disabled student in order to access academic spaces but not self-disclosing to teach as an instructor. Katie uses phenomenological disability studies to analyze disclosure at the intersection of disability and pregnancy as body-mediated moments (Draper, 2002). Nancy uses Hochschild's (1983) notion of "emotional labour" to explore how socio-spatial processes of disclosure can be an embodied form of "extra work" (e.g., managing perceptions of stigmatized identities).
\end{abstract}

\section{Résumé}

Dans cet article, les auteures utilisent des méthodes auto-ethnographiques élaborées collaborativement pour explorer les dynamiques animant la signification de «divulgation » d'un handicap en milieux universitaire et collégial. Puisant dans leurs propres expériences comme étudiantes au cycle supérieur et chargées de cours à l'université et au collège, elles examinent les façons normales de concrétiser la divulgation et de lui donner toute son importance, comme s'il s'agissait d'une relation interpersonnelle et d'une forme tangible de labeur. Leur dialogue démontre la nature variée de la divulgation d'un handicap. Par exemple, un étudiant peut se déclarer 
handicapé afin d'accéder à un service académique, tandis qu'un chargé de cours ne se déclarera pas comme handicapé pour enseigner. Aubrecht se sert d'études phénoménologiques sur les handicaps pour analyser leur «divulgation» au croisement d'un handicap et d'une grossesse comme des moments corporels interposés (Draper, 2002). La Monica adopte la notion de «labeur émotionnel» de Hochschild's (1983) pour explorer comment le processus socio-spatial de la «divulgation » peut être une forme incorporable de «travail supplémentaire »(p. ex. : gérer la perception d’identitéstigmatisée).

"I thought you weren't going to disclose?"

"I wasn't," my student furiously continues to tell me. "I had no intention of disclosing the nature of my disability to this professor. Nancy! I'm well aware of my rights. Without even thinking twice, I just handed my letter of accommodation to my prof."

By this time, I'm caught off guard, afraid she might have taken note of the quizzical look on my face. We had just spoken hours earlier about how she'd approach her professor to discuss her accommodation needs. She was confident and well-rehearsed about how she'd move through this process. What went wrong? But before I have a chance to probe, she continues,

"The prof then hesitantly said ... something to the effect of . . .'well I don't know . . . I don't think that's a good idea ... I'm not sure ... it's sort of compromising academic integrity."”

"Comprising academic integrity?" I subtly say trying not to act as though this is something I haven't heard before.

"Yeah so at this point all I heard was blah ... blah ... blah ... she was not going to 'level the playing field'... so I decided that I had to inform her that she could speak to my disability counsellor."

"That couldn't have been easy for you. I'm sorry this happened."

"Well, at the back of my mind I had all of this anxiety about having to go through the process of setting up another meeting to try and negotiate a fair solution. I realized that I had an upcoming exam in the next few weeks and would need to sort out this situation fairly quickly. I went on to tell her that I have a cognitive disorder. After iterating those two words she literally completely changed her demeanor and quickly said ... 'Well okay. You can use a memory aid; however, I have to approve it.' It's almost as if I said I have a deadly contagious disease, and she was in a rush to get me out of her immediate vicinity . .. It was pretty much like giving a blood sample in order to get accommodations."

\section{Where and When to Start}

One trouble with telling stories about disclosure is getting started. It is difficult to know where to start, especially when the story being told is not yours alone to tell. Stories implicate others (Adams \& Ellis, 2012). One way of addressing implication is through a collaborative dialogical approach, which we have attempted through narrative ethnographic approaches. This approach is grounded in Bakhtin's (1986) conception of dialogism. Recognizing that we already and inescapably exist in relation with others, we work in this paper to embrace an inter- and co-mingling of voices, treating words as always 
"half-ours and half-someone else's" (Bakhtin, 1981, p. 345). According to Keady, Williams, and Hughes-Roberts (2007), "Co-constructed inquiry uses dramaturgical terms and metaphor to communicate its underlying properties and personal/collective theory building processes" (p. 346). Our co-constructed narratives of disability disclosure have been embedded within personal narrative and biography.

At the same time as we recognize the difficulty of getting started, we also recognize that we have to start somewhere, and that in Western societies that somewhere has routinely been with the "I." We opened this paper with an autoethnographic story of how university policies can instrumentalize disability, implicating faculty, staff, students, and even administrators in that process. We did this in an attempt to "break silence by addressing understudied, hidden, and/or sensitive topics" (Philaretou \& Allen, 2006 as cited in Holman Jones, Adams, \& Ellis, 2013, p. 35), such as disability disclosure within spaces of the academy. Bochner (2013) explains,

Autoethnography is inquiry; something we can call experience is being inquired into, interpreted, made sense of, and judged. Facts are important to an autoethnographic storyteller; they can and should be verified. But facts don't tell you what they mean or how they make you feel. The burden of the autoethnographer is to make meaning of all the stuff of memory and experience-how it felt then and how it feels now. (p. 54)

We have used co-constructed narratives developed from a re-collection of Skype, longdistance telephone conversations, and email exchanges that we have analyzed using phenomenological disability studies (Paterson \& Hughes, 1999). This theoretical approach allowed us to explore the tensions that both animate the meaning of "disclosure" as it has been made to appear in academic spaces and occasion the appearance of bodily agency. Personal anecdotes, as understood from the frame of phenomenological embodiment and lived bodily experience, provide entry points to spaces of contestation that reveal the social and political conditions of the appearance of what we have come to understand as "disembodied disclosure"-an alienating process of identification that privileges institutionally ordered bodily schemas.

In these narratives, resistance to disembodied disclosure materialized in the form of individual and collective recognition of inequality, and as a struggle for subsistence in an institution that historically has prized visibility and productivity. We began from the assumption that participation in a co-constructed narrative is a phenomenological event, due to the disclosure and rediscovery of the lived body. Consciousness of disability and of ourselves and others as disabled is not simply a question of identification, as suggested by normative understandings of disability disclosure that treat disclosure as a tool. Consciousness, rather, "is intentional: it is directed toward something" (Ahmed, 2007, p. 27). In re-embodying disclosure, our work sought to make visible the "something" that organized perception of disability in higher education.

Our exchange as two academic instructors included a consideration of the intersection of disability and gender. Whether conceived as embodiment or organizing concept in society, the phenomenon of pregnancy has been used to make sense of relationality, and to question the power relations that condition recognition of where one body ends and another begins (see, for example, Rich, 1995). We both wrote from the lived experience 
of the female body (Young, 2005). While our narrative exchange recognized the historical underrepresentation of women in the academy (Aubrecht \& MacKenzie Lay, 2016), we wrote from the privileged social locations of white cisgender ${ }^{1}$ women who have benefitted from privileges of citizenship in the country we are learning and teaching in.

Our stories speak to status, gender, and disability-based inequalities within higher education. Telling them placed us at risk of what Mogendorff (2013) referred to as "dilemmas of double membership and dilemmas of disclosure" (para. 5). Due to the societal devaluation of disability and womanhood, publicly identifying as disabled women may negatively influence our current and future positions within the academy (Mogendorff, 2013). And yet this does not exempt us from taking responsibility for our privilege. We are implicated in the reproduction of inequitable structures, and with them the negation of racialized people, disenfranchised people, and people who identify as transgender and two-spirited. Although our shared stories focused on disability disclosure as made to appear in the lived experiences of the authors, we acknowledge the powerful role that race, gender, and institutional racism play in shaping who is successful in the academy in North America (see Aubrecht, 2009; Eisenkraft, 2010; Henry \& Tator, 2009; Muhs, Niemann, González \& Harris, 2012; Ng, 1993; Watts \& Erevelles, 2004). Disclosure is regulated by medical knowledge, bureaucratic organization, and professional expertise. Who gets to speak, and what counts as speech, has been gendered and racialized, and has become increasingly institutionalized (Aubrecht \& Mackenzie-Lay, 2016; Garland Thomson, 2002; Ng, 1993).

To work through the meaning of disclosure as a socially situated and interactional achievement, we follow Ellis, Adams, and Bochner (2011) for whom, "Autoethnography is an approach to research and writing that seeks to describe and systematically analyze (graphy) personal experience (auto) in order to understand cultural experience (ethno)" (para. 1). As part of this contradictory but commonplace reality, disabled instructors, fearing disclosure or being "found out," may pass on needed accommodations that may be available to them; accommodations that they, themselves, may recommend to students. Through anecdotes and narrative writing, we reveal the embodiment of disclosure for which disability passing becomes political; for example, when non-disclosing disabled instructors fear barriers to inclusion in academic communities and climbing the academic ladder, despite a solid record and credentials. An identified limitation of autoethnographic narrative writing is that it is not generalizable (Chang, 2013). We do not aim to generalize our lived experiences; rather our goal is to have our readers "feel" our stories with us, to experience those "aha" moments they might relate to, and to start a dialogue that opens a broader conversation on inequality in higher education.

Controversies around disability disclosure tend to be restricted to questions of whether and how to disclose, at the exclusion of questions about when to disclose, how we know which time is the right time to disclose, what we are supposed to do when this time comes, as well as what should be disclosed where, and to whom. According to Titchkosky (2010), Western bureaucratic practice socially organizes the meaning and appearance of disability, understood as a category of interpretation, in such a way as to make it fit a "not-yet" timeframe. We use Titchkosky's analysis of disability within the context of the not-yet time of disability to help us to make sense of this experience of waiting to tell-fearful, hopeful, and frustrating (for more on disability temporality see a special issue of Disability Stud- 
ies Quarterly, 2010; McGuire, 2013). How many experiences as a student and instructor can be described in terms of waiting? For job postings, for funding, for opportunities, for evaluation, for a response? Or waiting to write about non-disclosure until tenure?

\section{Wait to Tell!}

\section{Katie}

When I first found out I was pregnant, disclosure was a word that weighed heavily on me. I had just defended my dissertation days before, and had recently signed a contract as a part-time university instructor. Although I was delighted to learn I was pregnant, I was also worried about whether my $\mathrm{PhD}$ would be reduced to a "case" of a terminal degree. My future in the university was already precarious. I feared that if I disclosed my pregnancy, I risked ensuring my precarity. My worrisome way of making sense of the meaning of being a pregnant $\mathrm{PhD}$ was not all in my head. It was endorsed by empirical evidence of the disadvantages faced by working mothers in academic settings, histories of justifying gender-based exclusions on the grounds that a woman's place was in the home, and cultural mythologies of motherhood as incompatible with the working world (Aubrecht \& Mackenzie Lay, 2016; Castañeda \& Isgro, 2013; Reuter, 2005). I didn't want my story to end before I even got started. So, I waited.

In the end, I never told my new employers. One strategy I used to get around telling included removing myself from the hiring pool for the following term. I just didn't apply to teach the next term. Actually, the truth was, I couldn't apply. Or at least, I couldn't expect to stay in the union if I did apply, considering my due date was less than halfway through the term. According to my contract, more than two absences in a term would constitute a breach that could lead to removal of my name from the part-time faculty priority list. I would have to start all over, as if I had never been there, and would have to begin again with the distinction of absences on my record. Two classes is the equivalent to one "school" week. For the remainder of the academic term, I dog paddled through; many days carrying a book over my stomach. I ducked my head and swam quickly through hallways, held my breath, and arched my back until securing the safety and solitude of my office, where I could protect my pregnant body behind my desk. After withdrawing from the hiring pool and leaving the university, I entered the murky waters of Canadian employment insurance (EI), which provided a maximum of 12 months of financial assistance, using rates calculated for the "average worker".

I did not disclose. Active and deliberate withdrawal was my form of resistance to an inequitable space. I did my best to be the best I could be in the face of the stereotype of the "tragic figure" (Murugami, 2009, para. 13) of a disabled, pregnant, newly graduated, part-time academic. According to Murugami (2009), "This kind of conformity has often been referred to as normalization, but in actual fact it is assimilation since it requires that a person with disability strive to live a life like that of a non-disabled person" (para. 13). The lived experience of the mental and emotional labour and "body-work" (Purcell, 2011) involved in withdrawal taught me that what may appear as giving in or giving up, could also be interpreted as active resistance to inequity. Withdrawal disclosed embodied awareness of the university as an environment that can be unwelcoming and exclusionary to pregnant part-time instructors. 
In the university setting, gender and disability intersect in assumptions about "productive time" (Titchkosky, 2010). Within North American culture broadly, and specifically within the institutional culture of North American universities and colleges, the pregnant body is represented and normalized as a "natural" barrier to productivity. Pregnancy appears primarily in policies related to suspending time, as is visible in institutionally approved holds, extensions, absences, and leaves. Such policies often resulted from equity-focused social activism, and have been recognized as crucial to acknowledging and supporting "eligible" pregnant faculty and students. When I was working pregnant, the question, "Why are you here when you don't have to be?" was asked indiscriminately of me by people I confided in. Since my presence was temporary and contingent, four months at a time, what difference would my not being there make? Why bother working at all? I was excited at the thought of being a mother, but I had laboured more than half of my life to be a scholar, and I was given the distinct impression (at least in a public way) that the two roles were irreconcilable. You could be both, but not at the same time. And I was not even a mother-I was a 'not yet' mother and, as such, subject to a distinct form of surveillance. One that operated on the assumption that my physical presence at work threatened my fate, the fate of the students (the academic term for a whole population potentially placed at risk), and the fate of my unborn baby (Silbergeild, 2009).

Re-embodying disclosure, recalling disclosure as made to appear in and through my bodily being, has helped me to redefine disclosure as a question of heteronormativity and heteropatriarchy, of how pregnant workers ought to be using their time and where pregnant labour really belongs: in the hospital (medical sphere) or in the home (domestic sphere), not in public and not in the academy. Torn between home and office, I found myself more often in hallways and parking lots, body weighed down by a bag of books and a trail of tattered papers that I dragged from home to school to home again. You know that expression, Nancy, "time is of the essence"? Well, you know what? Time is also used to essentialize.

\section{Cautionary Tales of the Not-Yet!}

\section{Nancy}

"Don't do it! At least wait until you secure tenure before you disclose," my colleague interrupts me (Nancy). I nearly choke as I sip my wine as we discuss the possibility of disclosing to our employer. All I could do to distract my uneasiness was stare at the blossomed dandelion sitting on our patio table. He [my colleague] continues to express concern, telling terrifying stories of employees who disclose a mental health disability and are ostracized in spaces of the workplace. I cringe in my seat trying hard to hide my bodily discomfort.

Of course I know the implications of disclosure. This isn't new territory for me. I've been dealing with this all throughout my academic career. We both sit in silence-staring awkwardly at each other-waiting for the other to respond. I assume he's waiting for me say something, but I find myself unable to articulate my thoughts. Typically such a response would provoke a defensive reply citing the literature: employers are obliged to accommodate if they perceive a disability such as mental health (see Wilton, 2006). Instead, I say nothing. I sit in silence. With thoughts running through my mind, I'm disappointed that this conversation is headed to a complete stop. 
Forcing a fake smile, I say, "Yes, I share your concerns. I know you're right. Maybe now isn't the right time." And just as I respond, I feel a chill run up and down my spine. "I know all too well of the stigma you refer to as 'mental health' disabilities. I know you're only looking out for my best interests, but I can't help but question how, when, and if disability disclosure will ever have a place in the academy".

Not yet, continues to echo through my mind. Just wait.

"Hi Katie, I almost did it again!"

"Almost did what?"

"I almost disclosed." Just as I was signing another teaching contract for the term, my supervisor hands me two new course textbooks today. I'm grateful for the opportunity to teach another term, but I'm not sure how I'm going to pull this off. I should be able to get through the new texts in about a week, I'm told, leaving me plenty of time to prepare for next Monday, my first day of class. It's late Wednesday. I didn't know how to respond. I found myself staring blankly at the wall behind him [the supervisor], trying not to show the sheer panic inscribed on my body. I felt my face and chest beaming red. I can't have these read by Monday, I thought, not without accessible formatted textbooks. But disclosing this information would mean telling, and I wasn't ready, at least not yet.

Non-disclosure becomes harder to perform in spaces of the academy. I suspect he knows. It's almost slipped before you know-"I was awarded a disability bursary . . . no, no," I'd catch myself saying, "I meant travel bursary"-brushing this 'accidental disclosure' as a response to a research paper on funding for disabled graduates I was working on that day.

This extra work of concealing impairment is exhausting, time consuming, and emotionally charged (La Monica, 2013). Being on display takes work, and I'm sick of it. To disclose, to me, means no turning back. The consequences outweigh the benefits-at least right now. I can work harder if I just read faster. But at what cost? Having access to accessible formats of my texts would make it easier, but without them, I risk experiencing frustration that leads to fatigue and cluster headaches-then what? And even with accessible formats, non-disclosure doesn't address the fact that I will still need extra time. As a part-time contract faculty member I can't explain this to my supervisor. The extra work of normalizing one's body and mind becomes embodied for me-it's the only way that I feel I'll ever belong-even though I feel like a fraud. Don't get me wrong, I'm grateful for another teaching opportunity to add to my CV. I'm just not sure how much longer I can go on without having my accommodation needs met at the same time. In the end, I had a choice to make. Holding back tears that flooded my eyes, I told my supervisor I'd get through these texts over the weekend, knowing this would be next to impossible. Out of fear, I chose not to disclose.

As an instructor in the classroom, I am paid to teach. However, to do my job, I need accommodations-accommodations available to me as a disabled student, contingent upon disclosure-not as easily accessible to me as an instructor. Wilton (2006) echoes my fear of disclosure when he notes, "the extent to which individuals feel secure to disclose may ultimately determine their ability to access accommodations" (p. 27). Just as disabled students fear disclosure because of the stigma attached to disability (see for example, La 
Monica \& Chouinard, 2013), as an instructor, I don't want to be discredited as a scholar, fearing that I will not have teaching contracts renewed. The meanings I attach to the academy (Cresswell, 2004) influence how I manage, resist and/or confront discrimination-processes of disclosure that create extra work. In these paid spaces, I feel excluded when my academic identity demands the extra effort that might not be required of other non-disabled instructors.

Non-disclosure, to perform normally, to pass, in paid spaces of academia, I advocate is a form of "work" that Hochschild (1983) coined as emotional labour whereby employees "induce or suppress feelings in others to sustain the outward countenance that produces the proper state of mind in others" (p. 8). For some instructors, performing the work of emotional labour may include producing knowledge in the classroom (e.g., demonstrating that one is knowledgeable in the subject area to instill confidence in students about one's teaching abilities) (La Monica, 2013). As such, I don't want to display frustration in front of my students when reading material in class and I miss a word. I wonder if they are taking note of the errors I made on the blackboard. I don't want to be storied as a disabled instructor, scrutinized when students are upset with a grade, implying it must be due to my embodied disclosure, instead of justified as me being a (fair) hard grader (like other instructors).

\section{It's Complicated}

\section{Katie}

Nancy, I think it's complicated, I don't think anyone should have to disclose, and I don't agree that it is even safe to do so in all situations for all people. We need to question the notion of "all" that exists within both disability and academic communities. We need to complicate the meaning of disclosure, move disclosure out of the realm of identity politics, and examine what practices of disclosure can teach us about the university as a bio-bureaucratic system. By this I mean a bureaucratic system that operates according to a law of referrals. Universities and colleges are not just places, but cultural communities (Schutz, 1970, p. 80). The "cultural pattern" of universities and colleges is characterized by referrals. As a part-time contract faculty member with no job security, no benefits, and no certainty of pay past four months, who just found out she was pregnant, I felt alienated from my body and from the body growing inside me, alienated from myself and from the self the university expected me to be. The alienation I felt and lived, the alienation that held my breath and arched my back, also turned my attention toward the formidable authority of medical knowledge over the comings and goings of university life. Caught within this turn, not quite a jolt but far from gentle, I was emboldened to move quickly and covertly, moved by a burning feeling marked by smoldering cinders of shame and fear. I kept my bodies and selves close.

The way I understand it, fear and disclosure are irrevocably linked. Discourses of disclosure embody a fear that something is coming that must be contained. This understanding is steeped in my own lived experiences, which I have come to know as "complicated," experiences typified and normalized within university settings via the psychologizing language of mental health. Too easily, non-disclosure is redefined as deception, and when disability politics is reduced to identity politics, passing serves as a sorting mechanism separating authentic members of a cultural community from the imposters. There is a danger 
in making oneself visible as a passer, a poseur, as having passed an opportunity to come out. Once you know who and what you are, you have a moral, objective, and instrumental responsibility to become that person, fully and completely-body, mind, and spirit. There is a utility to coming out - it can provide access to resources and accommodations. And access is good for everyone, right? Or, at least most people. But coming out involves choosing one self, one body to be and to become, at least momentarily. Coming out as having a mental health condition, or being pregnant, have special implications. These two embodied ways of being straddle a paradoxical temporality. They may not always be visible, but their presence leaves traces that can never be fully absorbed nor erased.

The oft-cited Rosenhan experiment of the 1970s, "On Being Sane in Insane Places" (1973), serves as an exemplary case to think through what is at stake in disclosure. Rosenhan, a social psychologist, and his students declared that they were mentally ill to gain admittance into a mental health institution to observe everyday life from the vantage point of an inmate. They experienced no difficulties in gaining entry. When they later revealed their "true selves" to the institution's staff in an effort to leave, they were refused exit. Their protests were framed as symptoms of their disorders, that is, the true selves they had once claimed to be. Although it may seem taboo to suggest similitude in the experience of pregnancy, there are similar processes of objectification, linked to what could broadly be understood as the pathologization of motherhood (Matthey, 2010). Such lived bodily and minded (i.e., surveilled) experiences could be read as "cultural fetish," which Walks (2013) describes in the following way:

Women who are pregnant become pregnant bodies that are objectified and sexualized. Pregnant women and bodies are no longer private entities; instead, they are under the surveillance of both strangers and people they know. The view and treatment of pregnant women and their bodies is part of the larger cultural rendering of women into objects ... (para. 3)

What is more, as a cisgender-identified woman, the naturalization of my body also served to denaturalize queer and transgender pregnancies. Gently worded suggestions to leave work were based on the tacit assumption that I must have someone who could provide for my needs and the needs of the baby growing inside me.

Western patriarchal mythologies of "woman" creep up through crevices and cracks formed in the university's imagined subject and citizen-the androgynous (i.e., idealized, disembodied male) and autonomous individual-too naturally erratic, irrational, impulsive, unpredictable, too preoccupied to be profitably productive. The "bodily here" of the pregnant member of university culture is one of not-yet. That is, with the exception that the not-yet is not so much a matter of a fully materialized state of equality, so much as a fully materialized "bad thing."

The typical solution to the problem of alienation is oneness. I have claimed a disability identity within disability studies communities, spaces in which the referral is less obviously part of the cultural pattern. And yet, even in disability studies communities where you can be disabled because you say you are (Linton, 1998), the expectation is that you have come to such communities with bodies and selves that bear the labour of any number of bio-bureaucratic systems (Aubrecht, 2012). Nancy, as much as I recognize the need to support students and as much as I desire recognition that affirms impairment as 
a source of individuality and distinction as well as a site of suffering, I wonder how we can acknowledge distress, confusion, intensity, elation, and/or anguish in a way that does not involve a "referral" to offices through channels and processes that are highly medicalized-as your student expressed "like giving blood"-and that either result in or require acknowledgement of a "record"?

\section{Nancy}

Katie, I agree. I too claim a disability identity. However, my disclosure is contingent on the lived spaces. I want to share the fear I have as a non-visibly disabled doctoral student and academic worker without being accused of passing to normalize myself. I want to share outcomes of teachable moments I've been a part of, but fear what others might piece together in this fragmented story. I don't want to be found out, and I certainly don't want to risk the identities of others, specifically students who come to me with their confidential disclosure stories. But how can we change this system if $I$ continue to fear "what is coming"? I don't want to continue feeling ashamed of my disabled identity. I'm not. But I am tired of fighting ableist structures of the academy (see, for example, Jung, 2003) and having the extra work of proving my academic merit to others. I want to move freely in and out of spaces to disclose, when and where I choose, without feeling that I have no choice in the matter. Ultimately, I want the right to disclose if and when I chose to, not because I have to in order to do my job. How do I share important critical lessons that become teaching moments, without fearing what will come of my telling this story?

\section{Katie}

Thanks, Nancy. Our stories of disclosure speak to a disjuncture between institutional policies and practices within higher education and how these policies and practices are embodied and experienced. Through our conversation, I have come to recognize and appreciate the lessons that personal accounts of disclosure can teach about normal ways of relating to marginalization and exclusion within higher education. To illustrate, I will share one final story.

The office I had access to at one institution where I worked as a part-time instructor had a closet that I never opened the entire two years I taught there. At another institution, I was able to open the office closet, but I never had the privilege of using it. There was nowhere in the closet to hang my coat, it was stacked from the floor to the ceiling with boxes filled with files and folders that belonged to someone else.

So, in response to your question, maybe it is not so much a question of coming out but the need to interrogate unexamined assumptions concerning closets, and even fear. One thing we could think about is the routine bureaucratization of fear in higher education. A poignant example can be found in confidential emails and letters. In the university environments I have worked in, disclosure has typically appeared in the form of an email and/or letter from Student Services identifying a student who has been approved for accommodations. These bio-mediated textual practices and the perceptual styles they enforce make it possible (and easier, more convenient) to talk about disability because they treat disability as though it is simply a technical administrative issue. As a parallel to the administrative imperative for disabled students and educators to disclose, the disclosee is not supposed to ask about the meaning of disability, just accept that it is there. So I often 
meet students that have had administrative approval of medically verified impairments. I have the emails to prove it. But, meeting disability, well, that can be complicated.

When students came to let me know about their situation, I was so focused on meeting them as a "professor," with all the attendant heteronormative and masculinist assumptions about what professors look like, how they feel, and what they can do, that I closed the door on disability.

What would it mean to meet disability in the academy? Before we can adequately respond to this question, we need to examine how disability has been objectified and the ways of behaving that the (re)appearance of disability both recalls and provokes (MerleauPonty, 2004). Meeting disability in the academy can start with open-door policies, but it cannot end there. There has to be openness to being vulnerable to implication, whether of ourselves or others, even if it involves provoking unfavourable reactions. Being open isn't always easy. It can feel dangerous, even scary. Part of this is due to the fundamental ambiguity of disability (McGuire, 2010), and the fact that the meaning of disability, however regulated by professional medical knowledge and administrative objectives, is never fixed. Rather, the meaning of disability is co-constructed, built in what Titchkosky (2011) refers to as the "space between" disability and non-disability, building with it a sense of the "we" in the process (McGuire, 2010). The other part is the certainty that there will be consequences and the acceptance of consequences, which can at times produce an orientation to disability as something that is probably better off left at the door.

Nancy, I am troubled by the thought that students registered with accessibility services could complete a degree or diploma without ever being given a space or a chance to narrate disability, treating disability as story, a relation, rather than a reason (for accommodation, accessibility, etc.). University policy instrumentalizes disability and it implicates faculty, staff, students, and even administrators in that process. Administrative categories of disability become a currency that can be exchanged in the university setting for goods and services. However, they can also be thought of as a defence against the disclosure and being vulnerable to implication. Bureaucratically organized professionaldisability knowledge wards off this vulnerability. It instrumentalizes disclosure, reducing the meaning of disclosure to a question of categories and the reproduction of credentials.

Perhaps the trouble with disclosure can be understood in relation to the trouble with telling stories more generally, and has to do with knowing how and when to start. According to Frank (2000), "stories as acts of telling are relationships" (p. 354). Our co-constructed narratives of disclosure highlight the importance of relationships in academic culture and lived experience. As Tony Adams reminds us, "We can each attest to the ways our lives have changed because of living with others' stories; the stories have become our theories, frameworks for understanding, interpreting, and analyzing personal/cultural experiences ... ” (Adams, Holman Jones, \& Ellis, 2015, p. 80).

\section{Note}

1. Cisgender is an adjective that describes a person whose gender identification matches the sex given to them at birth. Cisgender can be used to differentiate between other gender identity categories such as transgender. It also signals the power and privilege that comes from being socially recognized as fitting within the gender/sex binary system (Aubrecht \& Mackenzie Lay, 2016). 


\section{Acknowledgements}

We thank CJHE editors, external reviewers, and Dr. Chelsea Jones and Dr. Mark Sherry for their constructive feedback. We also thank the organizers of the Disability Disclosure in/and Higher Education conference, University of Delaware, where we presented an early version of this paper in 2013. Funding from the Social Sciences and Humanities Research Council and Canadian Institutes of Health Research supported the development of this paper.

\section{References}

Adams, T., \& Ellis, C. (2012). Trekking through autoethnography. Qualitative research: An introduction to methods and designs. S. Lapan, M. Quarteroli, \& F. Riemer (Eds.). San Francisco, CA: Jossey Bass.

Adams, T., Holman Jones, S., \& Ellis, C. (2015). Autoethnography: Understanding qualitative research. New York, NY: Oxford University Press.

Ahmed, S. (2007). Queer phenomenology: Orientations, objects, others. London, UK: Duke University Press.

Aubrecht, K. (2009). Re-reading the Ontario review of the roots of youth violence report: The relevance of Fanon for a critical disability studies perspective. In G. Dei \& M. Simmons (Eds.), Fanon and education: Thinking through pedagogical possibilities (pp. 55-78). New York, NY: Peter Lang Press.

Aubrecht, K. (2012). The 'new vocabulary' of resilience and the governance of university 'student life'. Studies in Social Justice, 6(1), 67-83.

Aubrecht, K., \& Mackenzie Lay, I. (2016). Solidarity in the solitudes of student life: Contemporary women students discuss life and work in the academy. In E. Whitaker (Ed.), Solitudes of the Workplace: Women in Universities (pp. 118-135). Montreal/ Kingston: McGill-Queen's University Press.

Bakhtin, M. M. (1981). The dialogic imagination: Four essays. Austin, TX: University of Texas Press.

Bakhtin, M. M. (1986). Speech genres and other late essays. Austin, TX: University of Texas Press.

Bochner, A. (2013). Putting meanings into motion: Autoethnography's existential calling. In S. Holman Jones, T. Adams, \& C. Ellis (Eds.), Handbook of autoethnography (pp. 50-56). Walnut Creek, CA: Left Coast Press.

Brueggemann, B. \& Danforth, S. (2010). Disability in/and time. Disability Studies Quarterly, 3O(3/4). Retrieved from http://dsq-sds.org/issue/view/47

Castañeda, M., \& Isgro, K. (Eds.). (2013). Mothers in academia. New York, NY: Columbia University Press.

Chang, H. (2013). Individual and collaborative autoethnography as method: A social scientist's perspective. In S. H. Jones, T. Adams, \& C. Ellis (Eds). Handbook of autoethnography (pp. 107-122). Walnut Creek, CA: Left Coast Press. 
Cresswell, T. (2004). Place: A short introduction. Oxford, UK: Blackwell Publishing.

Draper, J. (2002). 'It's the first scientific evidence': Men's experience of pregnancy confirmation. Journal of Advanced Nursing, 39(6), 563-570.

Ellis, C., Adams, T, \& Bochner, A. (2011). Autoethnography: An overview. Forum: Qualitative Social Research, 12(1). Retrieved from http://www.qualitative-research.net/index. $\mathrm{php} /$ fqs/article/view/1589/3095

Eisenkraft, H. (2010, October 12). Racism in the academy. University Affairs. Retrieved from http://www.universityaffairs.ca/features/feature-article/racism-in-the-academy/

Frank, A. (2000). The standpoint of the storyteller. Qualitative Health Research, 10, 354-365.

Garland Thomson, R. (2002). Integrating disability, transforming feminist theory. National Women's Studies Association, 14(3), 1-32.

Henry, F. \& Tator, C. (Eds.). (2009). Racism in the Canadian university: Demanding social justice, inclusion, and equity. Toronto, ON: University of Toronto Press.

Hochschild, Arlie Russell (1983). The Managed Heart: Commercialization of Human Feeling. Berkeley: University of California Press.

Holman Jones, S., Adams, T., \& Ellis, C., (2013). Introduction: Coming to know autoethnography as more than a method. In S. Holman Jones, T. E. Adams, \& C. Ellis, Handbook of autoethnography, (pp. 17-47). Walnut Creek, CA: Left Coast Press.

Jung, K. E. (2003). Chronic illness and academic accommodation: Meeting disabled students' 'unique needs' and preserving the institutional order of the university. Journal of Sociology \& Social Welfare, 30(1), 91-112.

Keady, J., Williams, S., \& Hughes-Roberts, J. (2007). 'Making mistakes': Using coconstructed inquiry to illuminate meaning and relationships in the early adjustment to Alzheimer's disease-a single case study approach. Dementia, 6(3), 343-364.

La Monica, N. (2013, July). Negotiating Accommodations in Academia: A Matter of 'Extra Work.' Paper presented at Fourth International and Interdisciplinary Conference on Emotional Geographies at the University of Groningen, Netherlands.

La Monica, N., \& Chouinard, V. (2013). WARNING: Labels may cause serious side effects for learning disabled students. In A. Azzopardi (Eds.) Youth: Responding to livesAn International Handbook, (pp. 193-209). Rotterdam, NL: Sense Publishers.

Linton, S. (1998). Claiming disability: Knowledge and identity. New York, NY: NYU Press.

Matthey, S. (2010). Are we overpathologising motherhood? Journal of Affective Disorders, 120 253-266.

McGuire, A. (2010). Disability, non-disability and the politics of mourning: Rethinking the 'we.' Disability Studies Quarterly, 3o(3/4). Retrieved from http://dsq-sds.org/ article/view/1282

McGuire, A. (2013). Buying time: The s/pace of advocacy and the cultural production of autism. Canadian Journal of Disability Studies, 2(3), 98-124. Retrieved from http:// cjds.uwaterloo.ca/index.php/cjds/article/view/102 
Merleau-Ponty, M. (2004). The world of perception. New York, NY: Routledge.

Mogendorff, K. (2013). The blurring of boundaries between research and everyday life: Dilemmas of employing one's own experiential knowledge in disability research. Disability Studies Quarterly, 33(2). Retrieved from http://dsq-sds.org/article/view/3713/3231

Muhs, G., Niemann, Y., González, C., \& Harris, A. (2012). Presumed incompetent: The intersections of race and class for women in academia. Logan, UT: Utah State University Press.

Murugami, M. (2009). Disability and identity. Disability Studies Quarterly, 29(4). Retrieved from http://dsq-sds.org/article/view/979/1173

Ng, R. (1993). 'A woman out of control': Deconstructing sexism and racism in the university. Canadian Journal of Education, 18(3), 189-205.

Paterson, K. \& Hughes, B. (1999). Disability studies and phenomenology: The carnal politics of everyday life. Disability \& Society, 14(5), 597-610.

Purcell,C.(2011).Touchingwork:Anarratively-informedsociologicalphenomenology of holistic massage. Dissertation retrieved from University of Edinburgh https://www.era. lib.ed.ac.uk/bitstream/handle/1842/6310/Purcell2012.pdf?sequence=2\&isAllowed=y

Reuter, A. (2005). Subtle but pervasive: Discrimination against mothers \& pregnant women in the workplace. Urban Law Journal, 33(5), 101-150. Retrieved from http:// ir.lawnet.fordham.edu/cgi/viewcontent.cgi?article $=2252 \&$ context $=u l j$

Rich, A. (1995). Of woman born: Motherhood as an experience and an institution. New York, NY: W.W. Norton.

Rosenhan, D. (1973). On being sane in insane places. Science, 179(4070), 250-258. Retrieved from http://www.bonkersinstitute.org/rosenhan.html

Schutz, A. (1970). On phenomenology and social relations. Chicago, IL: University of Chicago Press.

Silbergleid, R. (2009). An introduction to gender studies: Pregnancy, parenting and authority in the university. National Women's Studies Association Journal, 21(1), 131-150.

Titchkosky, T. (2011). The question of access: Disability, space, meaning. Toronto, ON: University of Toronto Press.

Titchkosky, T. (2010). The not-yet-time of disability in the bureaucratization of university life. Disability Studies Quarterly, 3o(3/4). Retrieved from http://dsq-sds.org/ article/view/1295/1331

Young, I. (2005). On female body experience: 'Throwing like a girl' and other essays. New York, NY: Oxford University Press.

Walks, M. (2013). Feminine pregnancy as cultural fetish. Anthropology News. Retrieved from http://www.anthropology-news.org/index.php/2013/01/07/feminine-pregnancyas-cultural-fetish/

Watts, I. \& Erevelles, N. (2004). These deadly times: Reconceptualizing school violence by using critical race theory and disability studies. American Educational Research Journal, 41(2), 271-299. doi: 10.3102/00028312041002271 
Wilton, R. (2006). Disability disclosure in the workplace. Just Labour, (8)24, 24-39. Retrieved from http://www.justlabour.yorku.ca/volume8/pdfs/02\%20Wilton.pdf

\section{Contact Information}

Katie Aubrecht

Department of Family Studies and Gerontology

Mount Saint Vincent University

katieaubrecht@gmail.com

Katie Aubrecht, $\mathrm{PhD}$, is a critical health and disability studies scholar, and Canadian Institutes of Health Research (CIHR) Health System Impact Postdoctoral Fellow. Her research questions how embodied responses to the violence of prevailing discourses of power are assimilated under colonial knowledge regimes and in mental illness and aging in health regimes. She has published in Intersectionalities, Social Identities, Review of Disability Studies (RDS), Studies in Social Justice, Seniors Housing \& Care, and served as guest editor for special issues of RDS and Health, Culture and Society, and Canadian Journal of Disability Studies (forthcoming). www.katieaubrecht.com

Nancy La Monica completed her PhD in Human Geography at McMaster University. In her doctoral research, she used autoethnography to explore the experience of navigating the emotional geographic space of graduate school for non-visibly disabled students with learning disabilities and mental health disabilities. An integral part of her work includes exploring the emotion work and emotional labour that students do as they contend with processes of disablement in the academy. Nancy plans to continue this work to include disabled faculty members. Currently, she teaches in higher education, and is a researcher advocating for access and inclusion. 